\title{
Historical Pageantry and Progressive Pedagogy at Canada's 1927 Diamond Jubilee Celebration
}

\author{
James Miles
}

University of Toronto

\section{ABSTRACT}

Historians have argued that Canada's Diamond Jubilee of Confederation in 1927 represents one of the federal government's most sustained and successful attempts at nation building in the interwar period. In this mass outpouring of patriotic celebration, schools in particular played an important role in producing commemorative events, but also in constructing an engaging and accessible historical narrative for public consumption. At the heart of these events was the staging of hundreds of historical pageants, including many performances produced by teachers and students. This article examines how progressive pedagogies, such as active and play-based learning, came to be aligned with nation-building initiatives in widely produced historical pageants. Furthermore, it examines two published historical pageant scripts performed in Ontario's schools to reveal the dominant themes of the historical narratives being promoted in relation to Indigenous-settler relations, gender, and national identity.

RÉSUMÉ

Les historiens conviennent généralement du fait que le Jubilé de diamants de la Confédération, en 1927, constitue, de la part du gouvernement fédéral, l'une des tentatives de l'entre-deuxguerres les plus durables et les plus fructueuses d'édification de la nation. Lors de cet important mouvement de célébration patriotique, les écoles, plus spécifiquement, ont joué un rôle déterminant non seulement dans la production d'événements commémoratifs, mais aussi dans l'élaboration d'un récit historique destiné au grand public. Au centre de ces événements se trouvaient notamment de fameuses reconstitutions historiques dont certaines mises en scène et produites par les enseignant.e.s et leurs élèves. Cet article étudie la façon dont, à travers ces reconstitutions historiques largement produites, ces pratiques pédagogiques innovantes se sont alignées sur les efforts de construction d'une nation alors déployés. En outre, il analyse deux publications de reconstitutions historiques scénarisées jouées dans les écoles de l'Ontario afin de mettre en lumière les thèmes dominants, reliés à la nature des relations entre Autochtones et colons, au genre et à l'identité nationale, des récits historiques alors mis de l'avant. 
On the afternoon of May 26,1927, after months of rehearsing, six hundred children from thirty of Toronto's Catholic schools took to the stage in front of a capacity audience at Massey Hall. ${ }^{1}$ The production, a historical pageant entitled The Story of Canada, was performed as part of the celebrations for the Diamond Jubilee of Confederation. For a little over two hours, high school students sang, danced, narrated, and dramatized the story of Canada's past with "picturesque costuming, realistic stage effects and scenery transforming the drab old hall into an atmosphere of beauty." 2 The Globe newspaper went on to call the performance "one of the best examples of pageantry which has ever been placed before the Toronto public."3 Multiple newspaper reviews made it clear that the pageant was a "splendid affair" and noted its particular value in promoting a more comprehensive understanding of Canadian history.

The story told by the Catholic schools at Massey Hall was common among Canadian historical pageants at the time. Divided into eight episodes, the pageant dramatized what were considered the crucial moments in Canada's history in front of a changing backdrop that included a wigwam, a forest, and a lake. Written by Sister M. Geraldine of Saint Joseph's College School in Toronto, the pageant emphasized the significant role Christianity played in the building of Canada, while outlining a sweeping narrative of progress. ${ }^{4}$ All eight episodes were written around a theme, starting with Discovery and followed by Christianity, Chivalry, High Adventure, The Change of Flag, Loyalty, Prosperity, and Confederation. The narrative connected Indigenous peoples, or the "first Canadians," New France, the Conquest of 1763, Confederation, and finally Canada's "unswerving loyalty to the motherland" during the First World War. ${ }^{5}$

The star of the pageant was reported to be high school student Beatrice Conway, who portrayed an allegorical Canada and narrated the tale. Dressed all in white, Conway introduced the pageant with a scene later described by the press as "an Indian maiden calling to the Great Spirit to deliver her from the bondage of savagery, realistically presented by the beat of the tom-tom, the war dance, whoops and yells." Newspaper reviews highlighted Conway's impressive performance and overall declared the pageant to be a success. Toronto's Mail and Empire announced that the pageant was no mere chronological representation of history, but rather "an impressionistic picture of the phases through which the country has passed, so planned and costumed as to suggest the spirit, the sacrifice and the high adventure which has gone into the building up of the present Dominion." Such bombast and patriotism were common in Canada's Diamond Jubilee year. The year 1927 proved to be an important moment for Canadian nation building as extensive commemorative celebrations took place across the nation, including historical pageants in most cities and towns in which the Canadian public acted out the saga of the Dominion's development.

This outburst of historical pageantry was in part spurred on by the federal government, which saw the jubilee year as both a pedagogical and a patriotic opportunity. As Robert Cupido has shown, historical pageantry at the 1927 celebrations was endorsed by the federal government because of its supposed ability to foster national unity, social cohesion, and civic pride, though local organizers often appropriated 
and employed pageantry for their own purposes. ${ }^{8}$ However, it is clear from the official government planning that these celebrations were largely designed to be a vehicle for educating Canadians to be loyal, patriotic, and productive citizens. ${ }^{9}$ Schools and children were specifically targeted because it was believed that the improvement of youths' understanding of Canadian history would help secure the nation's projected future. More generally, politicians and educators envisioned the celebrations of 1927 as a mass educational event that had the capacity to "fire the imagination of our future citizens" and entrench an idealized Canadian identity for years to come. ${ }^{10}$

To meet such a patriotic goal, politicians, publishers, and educators constructed and promoted a variety of historical narratives to be performed and consumed in pageant form. While Diamond Jubilee pageants always celebrated the nation in some way, they also tended to embody the distinct values and beliefs of the writers who crafted them, and the organizations and groups that produced and performed them. For example, the Imperial Order Daughters of the Empire (IODE) produced pageants that emphasized Canada's imperial past, while pageants performed by some local committees stressed the contributions of different immigrant groups or "newcomers." 11 As discussed below, the "official" narrative promoted by the federal government, while still celebrating Canada's imperial past, emphasized more recent examples of progress and economic prosperity. This narrative in particular reflected the federal government's intention of developing a new nationalist sentiment that would, it was hoped, establish a more distinct Canadian identity.

This article explores the mutually beneficial relationship between nation-building efforts in Canada's Diamond Jubilee year and the progressive education movement. I consider how the government's nationalistic intentions aligned with progressive pedagogues' appeals to use child-centred and active learning approaches in Canadian classrooms. ${ }^{12}$ I argue that through the collaboration of these two movements, schoolchildren and teachers helped produce and consume a new national narrative in the form of historical pageantry. By closely examining the case of patriotic education in Ontario and two case studies of published historical pageants used in Ontario's schools, I provide insight into how pageantry was mobilized as a vehicle of both patriotism and progressive pedagogy. Through an analysis of the pageants, The Crowning of Canada and Canada: In Story and Song, I also demonstrate the form and dominant themes of the narratives that were being promoted, and how indigeneity, gender, and national identity were being represented and established in Ontario's schools.

\section{A Canadian Case of Pageantitis}

In the early twentieth century, a fascination for historical pageantry took hold across Britain, the United States, and Canada. ${ }^{13}$ As David Glassberg has explained, the "new historical pageantry" had its origins in the British Arts and Crafts Movement, which was part of an anti-modernist desire to promote traditions and community connections to a mythologized and folkloric past. ${ }^{14}$ Historical pageants, which began in Britain but quickly spread to the United States and Canada, mainly involved community groups that staged elaborate performances of songs, dances, tableaux, and 
short plays while dressed in period costume set against a backdrop of elaborate sets and scenery. Importantly, these pageants aimed to tell a romantic historical narrative that celebrated the local community.

The pageants staged in the US and Canada can also be understood as a method of securing a "native" identity for settler communities by inscribing continuity, or in other words, settler permanence and futurity, onto the land. ${ }^{15}$ This can be seen in pageant narratives that connected modern American and Canadian identities with Indigenous peoples and symbols in straightforward chronologies of peaceful progress. In the United States, the peak of historical pageantry was between 1910 and 1917, as communities created historical visions of themselves that emphasized a time prior to the perceived challenges brought about by mass industrialization, immigration, and technology. ${ }^{16}$ Historians have called this period one of "pageant fever" or "pageantitis" because elaborate and well-attended performances were regularly staged across Britain, Canada, and the United States. ${ }^{17}$

In Canada, the first significant state-sponsored historical pageant took place in Quebec for the 1908 tercentennial celebration of Samuel de Champlain's arrival in 1608. On the Plains of Abraham, performers acted out an imagined unified past that tied French, English, and Indigenous peoples together through a performative ritual. ${ }^{18}$ In post-First World War Canada, pageants gained in popularity as politicians and elites aimed to foster and consolidate a new national feeling in the wake of Canada's growing political autonomy from Britain, but also because of cultural and economic threats from the United States. ${ }^{19}$ Robert Cupido has convincingly argued that the 1927 Diamond Jubilee celebrations represented the federal government's most ambitious and sustained effort at nation building during this period. The range of commemorative events included national radio broadcasts, a national holiday of thanksgiving on July 2, Dominion Day parades in most cities, and the performance of hundreds of historical pageants across the country. ${ }^{20}$ The nationalistic motivations of the government's jubilee celebrations were primarily aimed at promoting social cohesion, loyalty, and patriotism with school-aged children playing important parts as both participants and spectators.

\section{The Government's Educational Vision for the Diamond Jubilee}

The federal government's vision for the Diamond Jubilee included schools and children playing a central role in the celebrations. During the parliamentary debates over Bill $65,{ }^{21}$ which established and funded a national committee for planning the jubilee, disagreements arose over committee membership, and in particular, the lack of educational representation. The committee proposed by Mackenzie King's Liberal government was dominated by business interests, politicians, and bureaucrats, and it was met with considerable resistance from critics on both the left and right of the prime minister. James Brady, Conservative MP for Skeena, BC, argued that an educational representative was absolutely necessary to emphasize and direct the committee's educational purpose, stating: "We know what it would mean if we enable the youth of Canada to come to a realization of the past history of the Dominion and to form 
some idea of unity for the future." ${ }^{22}$ MPs J. S. Woodsworth and Agnes Macphail also argued for more educators on the committee, specifically someone representing the teacher federations. ${ }^{23}$ In response to these challenges, Mackenzie King stated: "There is no question that the educational side of the celebration will be the first and main feature of it." However, King disagreed with adding representation from teachers or universities. ${ }^{24}$ In response to Brady's concerns, King responded: "If my honourable friend will run through the list of names he will find that a large percentage are those of university graduates and he may rest assured that the educational interests of the country will be well taken care of." ${ }^{25}$ Soon after King's dismissive comment, the debate was closed, and the National Committee for the Celebration of the Diamond Jubilee of Confederation (hereafter the National Committee) was established with an initial budget of $\$ 250,000 .{ }^{26}$ Despite its lack of formal representation from teachers, school boards, or universities, the work of the National Committee was focused and committed to the important role that the public education system would play in the Diamond Jubilee celebrations, and the committee was instructed to work with the provinces to develop the educational nature of the events.

The National Committee's initial educational efforts primarily focused on drawing student attention to the jubilee through souvenirs, memorabilia, and educational publications. Minutes from the committee's meetings show that the medals subcommittee spent significant time and money to create over two million bronze Confederation medals that were to be distributed to every school in Canada "to interest the school children of Canada in the celebration." ${ }^{27}$ Additionally, special gold, silver, and bronze medals were created to award the winners of contests in essay writing and oratory skills, and the booklet Sixty Years of Progress, which offered detailed economic statistics about the development of industry and resource extraction in Canada, was widely distributed to assist students in their research for such contests. ${ }^{28}$ The National Committee also produced plaques carrying the new Canadian coat of arms and the motto "Canada, Our Country" to be placed in every school. ${ }^{29}$ Such initiatives demonstrated the government's desire to build "a new national feeling" distinct from existing commemorative rituals in schools like Empire Day, which had traditionally emphasized ties to Britain. ${ }^{30}$

The National Committee also produced two booklets that offered suggestions for local committees planning their own jubilee celebrations. ${ }^{31} \mathrm{~A}$ four-page booklet offered general suggestions for local committees, such as involving different groups such as "school children, newcomers, Old settlers and Indians." A more lengthy booklet, Suggestions for Historical Pageants, Floats and Tableaux for the Guidance of Local Committees in Charge of Diamond Jubilee Celebrations, included a general sketch of Canadian history and illustrations of key themes in Canada's story. ${ }^{32}$ This second booklet can be used as evidence of the National Committee's preferred historical narrative for the celebrations. This story emphasized the post-Confederation era, including the settlement of western Canada, with themes such as economic development and prosperity. The titles of some of the accompanying illustrations give a clear sense of the narrative choices the committee was making: "Electricity," "The Melting Pot," "Forest Wealth," "Wealth from the Sea," and "Progress" (see Figure 1 for an example). 


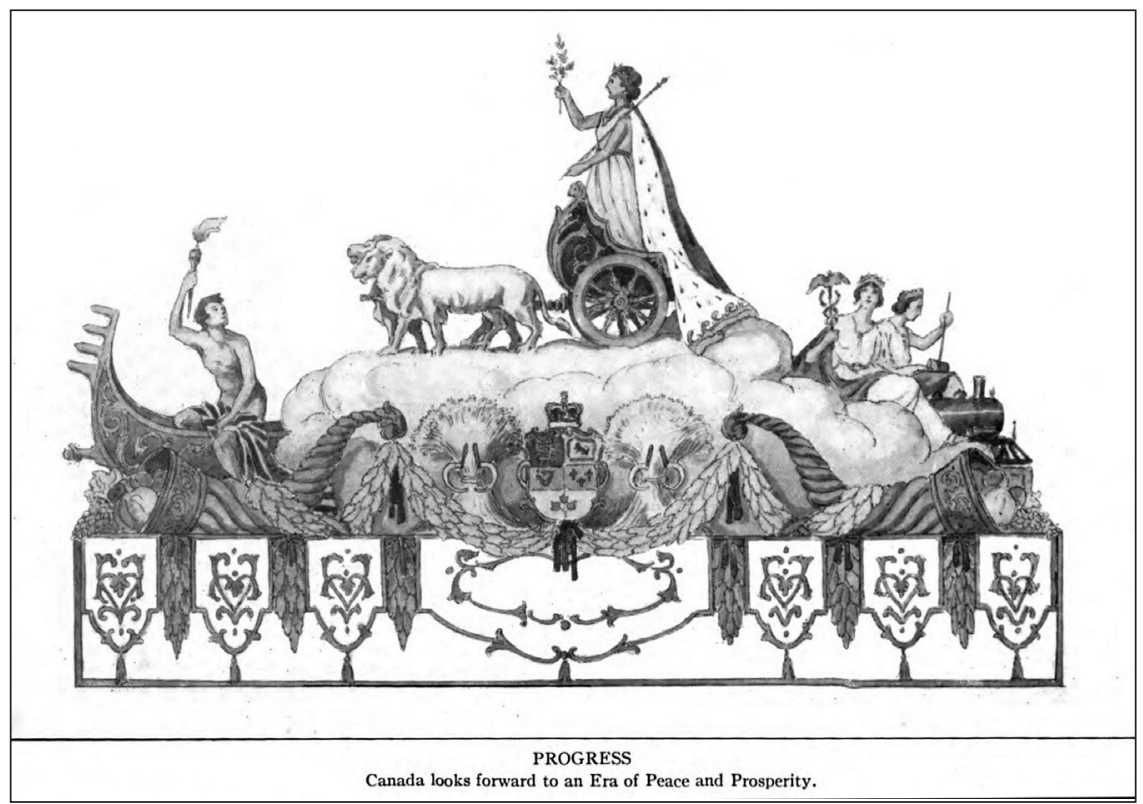

Figure 1. "Progress. Canada looks forward to an Era of Peace and Prosperity." This illustration is reprinted from Suggestions for Pageants, Floats and Tableaux for the Guidance of Local Committees in Charge of Diamond Jubilee Celebrations (Ottawa: Executive Committee of the National Committee for the Celebration of the Diamond Jubilee of Confederation, 1927), 2. Courtesy of HathiTrust, https://babel.hathitrust.org/cgi/pt?id=mdp.39015059502925orview=1 updrseq=4.

While the National Committee promoted the educational nature of the jubilee celebrations and the official narrative to be told, the planning of school-related events was left to provincial departments of education, administrators, and teachers. Provincial departments of education all responded enthusiastically with their own plans for celebrations. Annual reports from school superintendents from each of the nine provinces contained letters and reports noting the great enthusiasm witnessed at the celebrations. It should be noted that some reservations were reported, such as a complaint from teachers in New Brunswick that the Dominion Day celebrations on July 1 would "cause inconvenience," since they occurred after the school holidays had begun. ${ }^{33}$ Cyrille Delage, superintendent of schools in Quebec, requested that children, or as he called them, "the citizens of tomorrow," be "made objects of special attention." Delage wrote to all school commissioners and trustees and asked them to prepare "a special examination on the benefits and progress due to Confederation," which was to be preceded, accompanied, or followed by patriotic songs. ${ }^{34}$ No sources reveal how Quebec's students and parents received this request.

Following the festivities, the National Committee's Final Report announced successful celebrations involving schoolchildren across the nation. In almost all cases, these involved historical pageantry. ${ }^{35}$ Participation numbers reported to the National Committee by each province offer insight into the mass scale of these events: in Victoria, BC, two thousand children presented a "glorious pageant, a living panorama 
of Canada's history;" at Hastings Park in Vancouver, three thousand children performed a pageant for an audience of twenty thousand; in the small community of Carman, Manitoba, "2000 gaily attired boys and girls" took part in a pageant; and in Halifax, fifteen hundred children presented a "splendid pageant witnessed by 30,000 people." 36 What these numbers do not reveal is just what each pageant entailed and the role teachers and schools played in their production. However, in Ontario, more detailed evidence exists about the form, content, and production of historical pageants that involved teachers and students.

\section{Patriotic Education in Ontario}

Before patriotic pageantry became popular in the 1920s, Ontario's schools already had a firmly established patriotic tradition in Empire Day. This annual ritual celebrated the British Empire and took place on the school day that preceded the May 24 holiday commemorating Queen Victoria's birthday. The invention of prominent imperialist Clementina Trenholme, Empire Day was first observed in Ontario on May 23, 1899, and was later observed across the country, and eventually, throughout the British Empire. ${ }^{37}$ One of Empire Day's strongest advocates at the time was George Ross, who was Ontario's minister of education between 1883 and 1899, before going on to eventually become premier. ${ }^{38}$ Empire Day's popularity in Ontario's schools quickly increased in the early 1900s, with a patriotic focus on the British Empire's military triumphs.

In 1918, Toronto clergyman Henry John Cody became minister of education and immediately moved to strengthen patriotism in schools in part by reinstating history as a mandatory high school entrance examination subject. ${ }^{39}$ Cody promoted both Canadian and British history, declaring that "the value of the subject in promoting patriotism, in providing material for a clear grasp of Canadian civics, and in expanding Canada's imperial relations and her place in the Empire is generally recognized." ${ }^{40}$ In the interwar period, patriotic education was further promoted by Ontario's Department of Education, which produced annual Empire Day booklets that offered suggestions for teachers and students about how best to carry out the celebrations. Educational historian Robert Stamp has called Empire Day the most important patriotic ritual for students in English Canada at the time, noting its main purpose was not only a celebration of the British Empire, but also to promote militarism and the assimilation of new immigrants. ${ }^{41}$

In the 1920s, tension developed between Empire Day's imperialistic and militaristic nature and national and global shifts that emphasized peace and internationalism. In particular, the creation of the League of Nations and Mackenzie King's desire to promote a new national sentiment based on distinctly Canadian achievements did not align well with a celebration of the British Empire and war. However, in Ontario there was resistance to abandoning the Empire and supporting the League of Nations. The Department of Education's 1925 Empire Day booklet began with the defiant statement: "The greatest league of nations in the world is the British Empire and it will be for many years to come." ${ }^{2} 2$ The militaristic overtones of the 
booklet were clearly communicated in such statements as "True patriotism can never be satisfied with fighting foreign enemies. It must fight against every evil within our Empire," and "Patriotism demands self sacrifice." 43 Thinly veiled critiques of anti-imperialism and internationalism ran throughout the suggested celebrations for Empire Day in the early 1920s, but by 1927, Ontario's premier and minister of education, Howard Ferguson, took a more conciliatory tone to incorporating the new Canadian nationalism alongside demands for loyalty to the Empire. In an address to teachers, Ferguson declared that Empire Day and the Diamond Jubilee of Confederation celebrations were "so closely related to each other they should happily be joined in one commemoration." ${ }^{44}$ Ferguson's move to bind these two events and promote a distinct Canadian identity reflected a shift in Ontario's education system away from imperialism and towards "Canadianization." 45 As Robert Stamp has pointed out, this shift in the meaning of Empire Day was also affected by subtle changes in Ontarians' attitudes and outlooks, influenced by the growing presence of American popular culture. ${ }^{46}$ This also showed the malleability of Empire Day and its ability to adapt to the times. This is also consistent with what Martel, Ward, Belliveau, and Bos found in their investigation of Empire Day, who noted that, by 1928, Empire Day was calling on schoolchildren to celebrate both Canada and the Empire. ${ }^{47}$

As with other provinces, Ontario's government greeted the federal government's requests for involvement in jubilee celebrations with enthusiasm and later described the provincial celebrations they sponsored as "epochal." ${ }^{8} 8$ Premier Ferguson's additional portfolio as minister of education was credited in the subsequent provincial report as partly responsible for such an enthusiastic response in the schools. Alongside celebrations that began with Empire Day in May, Ontario also distributed the required medals and plaques, produced its own booklet on the Fathers of Confederation for use in high school history classrooms, and promised to introduce a high school entrance exam question in 1928 on the topic of Confederation. ${ }^{49}$ The National Committee also reported that pageants and parades occurred in most urban centres across Ontario.

The role of schools and children in Toronto's jubilee celebrations was particularly well documented by the press and in official school board, city, and provincial reports. Alongside the Catholic schools' pageant discussed previously, schoolchildren took part in a variety of pageants and other commemorative events throughout the spring and summer months. At Toronto's Normal Model School, a historical pageant that told the story of Canada from the conflict between General Wolfe and Marquis de Montcalm to the present day was prepared by teacher Miss Laven and was performed for the rest of the school on June 29. ${ }^{50}$ In the Toronto suburb of Aurora, the local mayor presented students with a hundred-pound cake declared by the Globe to be "the largest cake ever seen in Aurora." ${ }^{51}$ On Dominion Day, children from schools across Toronto were assigned to specific locations to decorate monuments and graves of the "Fathers," while thousands of spectators witnessed hundreds of children take part in a "military and historical pageant" in the form of a parade containing thirty-five floats. Organized by the Toronto's "Parade and Pageant Subcommittee" and directed by Roy Mitchell of Hart House Theatre, the five-mile pageant took Torontonians through Canada's history from "Leif the Lucky" to "The Birth of the 
Machine." ${ }^{2}$ As the photograph of the float for the "Earliest Canadians" (see Figure 2) reveals, non-Indigenous schoolchildren dressed up and performed as stereotypical "Indians." As historian Sharon Wall has explained, it was common at the time for middle- and upper-class white children to "play Indian," especially in public performances and at summer camps. ${ }^{53}$ In this case, boys from a local Catholic school, De La Salle College, acted as "bronzed Indian warriors." Unlike pageants performed for the federal government's celebrations in Ottawa, which included and encouraged the involvement of Indigenous communities, it appears from reports and photographs that there was little or no Indigenous involvement in the historical pageantry that took place in Toronto. ${ }^{54}$

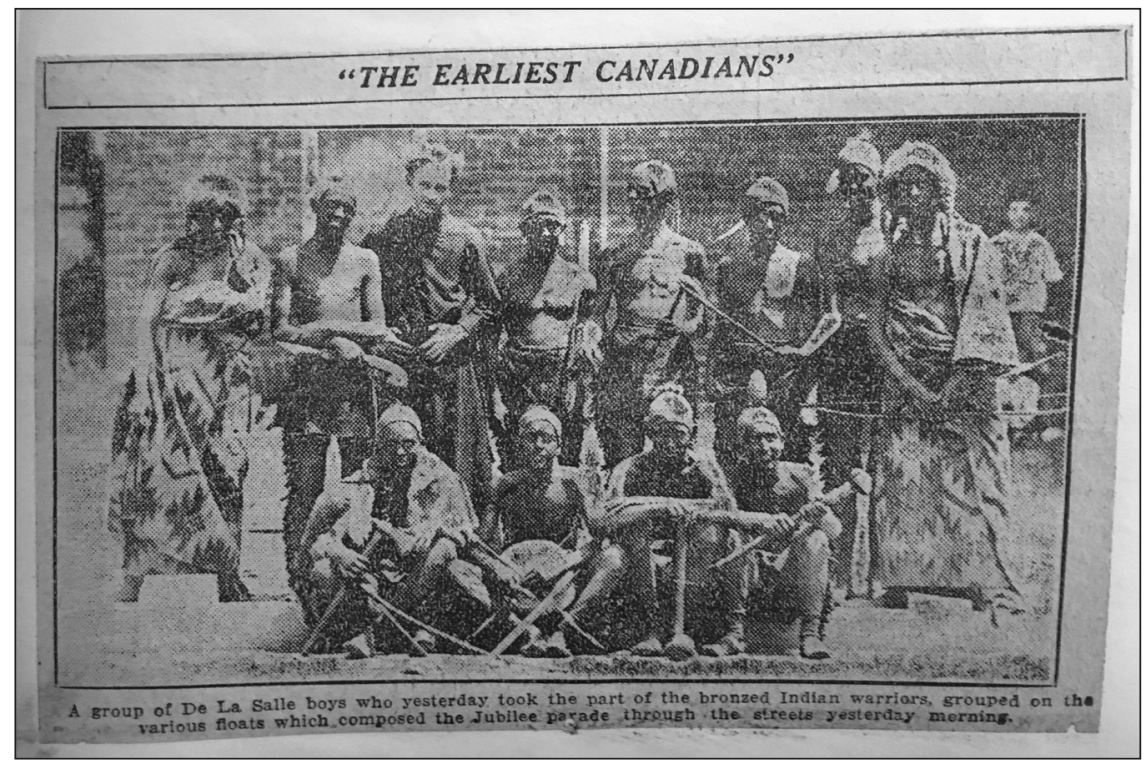

Figure 2. This photograph of the "Earliest Canadians" was published in the Mail and Empire on July 2, 1927. The caption reads: "A group of De La Salle boys who yesterday took the part of bronzed Indian warriors, grouped on the various floats which composed the Jubilee parade through the streets yesterday morning." Courtesy of the Archives of Ontario, Fonds F 1067 Box MU 750, barcode B294016.

The parade's opening float was distinct in that it symbolized the parade's theme rather than presenting a specific historical event or development like the other floats. The float was titled "The Child at the Gate," and it introduced the parade's futureoriented narrative, which envisioned a hopeful and prosperous outlook for young Canadians. The Mail and Empire described the scene, noting that a hundred high school girls dressed in white and carrying garlands of flowers led the parade "to wonderful effect." 55 They were followed by a "single boyish figure gazing ahead through a great gateway" standing above the words "we hold Canada in trust for him." ${ }^{56}$ In Toronto's historical parade, as in other commemorative events, the role of educating young citizens for Canada's future loomed large. 


\section{Pageants in Schools: A Mix of Progressivism and Patriotism}

Given the scale of the Diamond Jubilee celebrations and the starring role for Canada's youth in historical parades and pageants, it is clear that schools were a key site of preparation and enactment. As with Empire Day, it is difficult to think of the success of these productions without the dedication and enthusiasm of teachers. ${ }^{57}$ Questions remain, however, around what role classroom teachers played and what form pageants took in Canadian classrooms. One of the challenges encountered when researching pageantry in schools is that many performances did not even take place in the schools themselves. For example, notable publisher and literary critic Lorne Pierce promoted the use of dramatization and historical pageants in Canadian

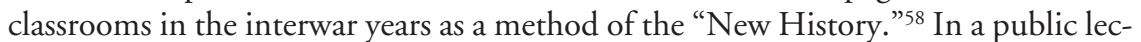
ture at Mount Allison University, Pierce cautioned that he had in mind something quite different from historical pageants that were "already written and only require rehearsal." ${ }^{59}$ Pierce recommended that students and teachers should produce their own historical pageants, preferably outside. Pierce suggested that they be produced "on the banks of some river or lake," with historical events chosen and crafted into dramatic episodes by the students. For Pierce, the main goal of "history as drama" was for students "to reconstruct and interpret the past, making it vivid and meaningful." ${ }^{60}$ Unfortunately for educational historians, this form of historical pageantry is inherently ephemeral and presents a challenge for understanding and interpreting the nature of historical pageants in schools. While there is a general lack of documentation on the methods employed by teachers who used pageants as pedagogy, there are some sources that provide useful insights into why pageants were being used and how such performances unfolded in school settings. These sources offer considerable evidence about the content and form of pageants written by educators, as well as published advice about the benefits and challenges of producing pageants in classroom contexts.

The now-defunct monthly education journal, The School, published by Ontario's College of Education, is a valuable source for understanding the relationship between historical pageantry and history education in the interwar period. It was also one of the few Canadian publications in which educationists could advocate for progressive educational reforms. ${ }^{61}$ In the 1920 s, The School published a range of articles written by teachers and instructors at Canadian normal schools offering advice and guidance about teaching history, staging pageants, and the general purposes of history and citizenship education. A 1927 editorial offered several arguments for focusing on history education during the Diamond Jubilee celebrations:

As the pupil learns something of the primitive conditions of settlement in this country and the hard tasks of the pioneer ... he may well feel a thrill of pride as he sees what has already been achieved by their industry and integrity — a firm foundation for even greater achievements in the twentieth century in which he may have his part to play. ${ }^{62}$ 
Along with providing lofty nation-building objectives for teaching history, The School also published articles that discussed the challenges and offered advice for introducing progressive pedagogies and staging historical pageants. ${ }^{63}$ In 1926, a teacher named Shirley Muir offered a reflection in The School on staging Minnie Williams's pageant, The Romance of Canada. ${ }^{64}$ Muir's article about the pedagogical practices of producing pageants reveals that pageants were often adapted from published scripts with multiple teachers and classes involved. Muir's article also shows that historical pageants were not just the domain of specialized history or drama teachers, but tended to be produced by multiple generalist teachers at the elementary or middle school level.

Muir described the pageant rehearsal process in depth, writing that much attention was focused on perfecting costumes, with each student "wholly responsible for his or her own, but all students were urged to consult the teachers." ${ }^{.5}$ Muir explained that most students researched "authentic" drawings of the historical figures they were to impersonate in the library, while also noting that confusion emerged when popular representations blended with the "authentic" representations found in history books. One young girl became convinced that in order "to impersonate Laura Secord it was necessary to carry a box of candy dedicated to that heroine's memory!" 66 This error of authenticity, related to a popular advertising campaign at the time which used Secord's image, was only rectified minutes before the performance began. For Muir, the biggest challenge in staging the pageant was student inattention and distraction. When describing the benefits of staging the pageant, Muir made no mention of developing historical understanding, cultivating citizenship, or inspiring patriotism. Instead the most important benefit Muir identified was the "friendly feeling developed between pupils and staff and the esprit de corps engendered from prolonged work on the parts." ${ }^{67}$ The author's lack of interest in nation building, citizenship, or patriotism provides an interesting juxtaposition to politicians' objectives and motivations for promoting historical pageants. This also raises an interesting contrast between the nation-building goals of the overwhelmingly male politicians and the community and skill-building goals of the overwhelmingly female teacher workforce. It also reveals, perhaps unsurprisingly, that Muir explicitly valued pageants because they helped develop community and skills, including public speaking, through a cooperative and collaborative class project.

Muir's article demonstrates that while the educational goals of producing pageants may not have been agreed upon, many Canadian teachers took up pageants with enthusiasm. I argue this was partially the case because the intended purposes or educational outcomes of pageantry were malleable and could be conceptualized as a pursuit of progressive education, of patriotism, or both. Just as Cupido has demonstrated that ethnic minorities and Indigenous peoples appropriated pageantry in 1927 to reflect their own values and identities, so too did teachers. ${ }^{68}$ Some teachers may have used pageants in their classrooms because the nature of pageants intrinsically required pedagogical approaches associated with progressive education, such as "active" or "hands-on" learning. Pageants also fit nicely into progressive education's view that learning should take place both in school and out, with the purpose of 
developing youth who could eventually be described as well-rounded citizens. Yet at the same time, pageants led students to embody heroic and patriotic narratives that could be seen to be cultivating social cohesion and loyalty to the nation or empire.

It is important to remember that progressive education itself is a malleable term with multiple understandings of just what is "progressive." As Amy von Heyking has explained, progressive education reforms in Canada were based on many different ideas and were often described using terms such as "child-centred," "active learning," "learning by doing," and "democratic education." ${ }^{69}$ Progressive educators also included social meliorism as a key goal of their philosophy. Historian Cynthia Comacchio has argued that the commitment to progressive education in Canada was designed "to uplift the masses" and to inculcate youth into certain values and behaviours that promoted citizenship. Progressive educators began to see public schools as a broader institution that needed to provide young people with much more than academic knowledge. According to this line of thinking, pageants were both a curricular and an extracurricular endeavour, in which historical knowledge and active learning about citizenship and values could take place. ${ }^{70}$

While progressive education was notably slower to make headway in Canadian than in American schools, changes to normal school curricula and discussions of progressive education in the pages of The School reveal that these conversations were happening and were influencing teachers' practices. ${ }^{71}$ Within this context, history teachers and historians were also debating how Canadian teachers might take up or reject the pedagogical proposals of the "New History" that were garnering much attention in Britain and south of the border.

In the United States in the early 1900s, progressive educators including John Dewey and Charles McMurray had been advocating for some time that methods for teaching history needed to be reformed. ${ }^{72}$ They argued that "play-based" and performative activities were the best way to learn about the past. This included using skits, songs, crafts, plays, and dances to generate children's interest in history. ${ }^{73}$ In his book, Special Methods for History, McMurray, a teacher at the Illinois Normal School, argued: "If a boy constructs a wigwam, dresses like an Indian and makes bows and arrows to shoot with, he comes into closer sympathy with Indian life. If a child produces a log house and its surroundings, he gets closer to the reality of pioneer life." ${ }^{74}$ The case made by progressive educators to reform history teaching did not explicitly call for historical pageantry as pedagogy, but their writing established the pedagogical and theoretical case for the use of pageantry that eventually became a wider cultural craze throughout the 1910s and 1920s. During this same period, articles began appearing in American education journals that explicitly advocated for historical dramatization in the classroom. ${ }^{75}$ Horace Brown of the Massachusetts Normal School called for "a steady and healthy increase in dramatization," which, in his view, included: "plays, pantomimes, tableaux and pageants." "B6 Brown called for pageants to take place in classrooms at least once a month with student-selected topics that could "be made to fit any dramatic situation. I urge its use by teachers."77 Whether educators' calls for the use of pageantry and dramatization were actually taken up by many teachers is difficult to determine; however, there can be no doubt 
that this approach to teaching history was regularly discussed in educational conversations about history teaching.

Historians have shown that in Canada, most provincial departments of education and teachers were slow to adopt progressive education in any systematic way. In contrast with provinces like Alberta, where the "new education" was embraced more quickly and enthusiastically, Ontario's Department of Education was particularly reluctant. ${ }^{78}$ Despite a reputation for pedagogical conservatism, important conversations about reforming history teaching were ongoing in Ontario, as teachers grappled with ways to make history more engaging and interesting. While historians and politicians continued to advocate for approaches to teaching history that emphasized patriotism and moral decision-making, ${ }^{79}$ school teachers, instructors at normal schools, and advocates of progressive education in the media made the case that history needed to be more exciting, engaging, and feature greater student activity. For these educators, history didn't have to be dreary, dull, and boring. Instead the natural "romance and adventure" that was said to embody stories from the past needed to be unleashed in classrooms. ${ }^{80}$ In the Globe's regular "Talks on Education" section, the Toronto newspaper announced in 1927: "Pageants are now the order of the day. It is quite natural that in this Canadian jubilee year we should turn our thoughts to dramatic incidents in our history, and that schools and national organizations . . . should present these in spectacular form." ${ }^{81}$ For other progressive pedagogues, historical pageantry was the answer to lack of student interest in history, and The School provided a platform for them to promote historical dramatization. In 1927, Ruth and Evangeline Lewis of Hamilton, Ontario, wrote that history can be a "delight" for students if it is turned into a series of progressive episodes like a book, stating: "What a thrilling book, kings, queens, and knights for characters, and adventure piled on adventure!" 82 The official history teaching methods book for elementary schools used in Ontario's normal schools also advocated dramatization as one way of "making history real." The methods book, read by pre-service teachers, suggested that

learning by doing has become almost commonplace. But it is still the chief argument for dramatization in history. The pupils impersonate historical characters and events as well as show the machinery of government in action. It is the play element that appeals and acts as a motive, inducing pupils to learn their parts. ... Abstract truths are more clearly understood by such dramatization. ${ }^{83}$

The advocacy for the dramatization of history teaching at the time reveals that progressive education in history classrooms was on the rise in Ontario's classrooms in the 1920s, although it is unclear to what scale these reforms were adopted in history classrooms, or the impact that acting in the pageants had on students.

\section{School Pageants Written for the Diamond Jubilee}

To better understand the use of historical pageantry in Ontario's classrooms and to demonstrate how progressive and patriotic pageants were realized, we can look to 
two pageants that were used in Ontario's schools: The Crowning of Canada, written by Nellie Medd, and Canada: In Story and Song, written by Jean Gertrude "True" Davidson. ${ }^{84}$ The educative considerations and suggestions provided in these two published pageants might be attributed to the fact that both authors were teachers. ${ }^{85}$ Though the use of historical pageants in schools in Canada was not a new phenomenon, these pageants offered interpretations of Canada's history that deserve attention in their own right, because they were both written specifically for the Diamond Jubilee of Confederation and widely distributed. ${ }^{86}$

\section{Nellie Medd's The Crowning of Canada}

In 1927, the Ontario Department of Education distributed to all of its schools an eight-page historical pageant, The Crowning of Canada, written by teacher Nellie Medd of Exeter. ${ }^{87}$ Written specifically for the Diamond Jubilee, The Crowning of Canada provides a glimpse into one historical pageant that was likely performed by many children in classrooms across Ontario. ${ }^{88}$ Medd's pageant was written with fellow teachers in mind, and it included instructions and suggestions for sets and scenery, costumes, stage directions, and selecting certain types of students for specific historical roles. The Crowning of Canada was a relatively short pageant and could easily be staged during one classroom lesson. The pageant featured twenty-five speaking roles (thirteen boys and twelve girls), though Medd made it clear that these numbers were flexible and dependent on how many students were available. ${ }^{89}$ The characters written by Medd were either key historical figures such as Montcalm and Wolfe,

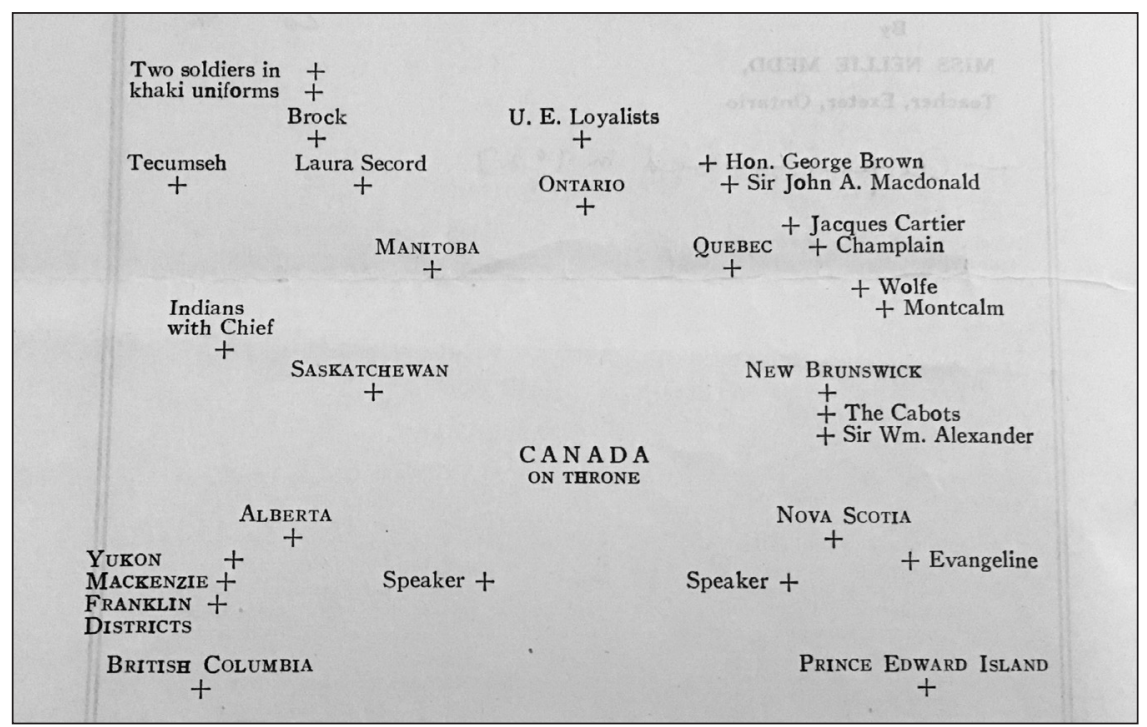

Figure 3. This diagram shows the ideal arrangement for characters in Nellie Medd's The Crowning of Canada (Toronto: King's Printers, 1927), 2. Courtesy of the Archives of Ontario, Centennial School Project Files RG 2-126, barcode B291905. 
groups referred to as "historical" such as "Indians" and United Empire Loyalists, or geographical representations such as districts or provinces (see Figure 3).

The pageant's premise is that Canada, ideally played by a girl dressed in white cheese cloth trimmed with maple leaves, ${ }^{90}$ has invited historical figures, provinces, and other groups to a birthday celebration in which each character brings a crown as a gift. The pageant proceeds with each character speaking in rhyming couplets. For example, "Canada" opens the pageant with the following introduction:

My children gather round me close, and, as their arms entwine,

They say: "Come celebrate this sixtieth year of thine."

They talk of love and loyalty, of glory and renown,

They tell me each has brought to me a birthday crown. ${ }^{91}$

Provinces then speak in order of their "entrance into Confederation — from youngest to the eldest," beginning with Saskatchewan and Alberta. When the pageant reaches older provinces in central Canada and the Maritimes, historical characters begin entering the storyline. For example, after Ontario is introduced, the associated historical figures tell a story of the province starting with Brock and Tecumseh, and then moving on to Laura Secord, George Brown, and finally, John A. Macdonald. The contributions of each province largely revolve around what natural resources or economic goods and labour they provide the Dominion. Alberta brings "coal for your homes and factories, gold that we wash and sift, and sugar from our beet fields - this is my birthday gift." ${ }^{2}$ After each province speaks, the student then places a crown on the floor around Canada until a circle is formed. Towards the pageant's finale, some minor tension is planned as Quebec states: "As thy eldest child I claim the right, thy regal head to crown" though this action was halted as "a band of Indians" intervenes, claiming that the right to crown Canada belongs to them, as they "are the oldest race this country knows." The pageant concludes with the "Indian Chief" crowning Canada and all the students singing "crown her with many crowns" to the tune of Diademeta. ${ }^{93}$

\section{True Davidson's Canada: In Song and Story}

Jean Gertrude "True” Davidson was a prominent and successful politician and writer in Toronto in the interwar period. ${ }^{44}$ After graduating from the University of Toronto and receiving her teaching certificate at the Regina Normal School, Davidson became a high school English and history teacher, teaching first in Saskatchewan and Manitoba. Davidson returned to Toronto, and after obtaining her MA, she became a teacher at Havergall College, a private girls' school. During this period, Davidson began writing children's books and other educational publications for J. M. Dent and Sons, a well-known Canadian textbook publisher. In 1927, the company published Davidson's Canada: In Story and Song, a historical pageant written for the Diamond Jubilee celebrations and designed to work in conjunction with Dent's Canadian History Readers, written by Donalda J. Dickie. ${ }^{95}$ Canada: In Story and Song is far 
more complex and lengthy than Medd's The Crowning of Canada and included over sixty characters that spanned Canada's past from "Indians" to "Soldiers in Flanders Fields." The complexity of the language and the available speaking roles suggest that this pageant was far more likely to be produced by middle school or high school students. It retains familiar elements common to other pageants, such as a "naturalistic" set that includes teepees and outdoor scenes, a female student in a white costume representing Canada, and various well-known historical figures.

Dent's Canadian History Readers provided much of the historical context and imagery that was intended to be used in Canada: In Story and Song. The reader series is a collection of eight books for young readers that feature short descriptions of events and figures in Canada's history accompanied by numerous illustrations. Book 2, which is heavily referenced in parts of Davidson's pageant, is titled All About Indians. ${ }^{96}$ Often the cross-referencing between the pageant and the readers was done to provide more historical context to the teacher or student as well as ideas on costumes and scenery. For example, for a scene that involves Indigenous peoples, Davidson suggests a costume of "a head-dress as described on page 9 of the Dent's Canadian History Readers Book II." ${ }^{77}$ This reference then connects to a description of a nine-year-old Indigenous boy named "Little Bear" and provides instructions for making your own "War Bonnet" headdress (see Figure 4).

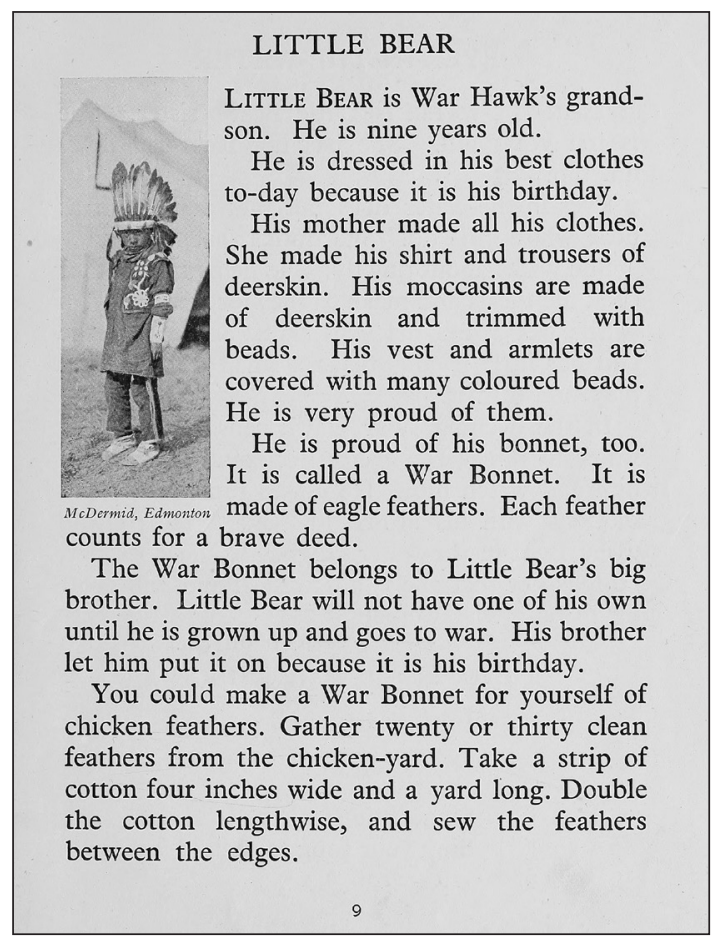

Figure 4. Page 9 of Donalda Dickie’s Dent's Canadian History Readers: All About Indians. Courtesy of Internet Archive, https://archive.org/details/dentscanadianhis02dick. 
Davidson's pageant begins with an episode in which the provinces and Canada announce that they will recount the history of Canada for the Diamond Jubilee celebration. The narrator tells the audience that they will first jump back four hundred years to a time when "our Indian brothers, tawny and red, were the first Canadians born and bred." ${ }^{8}$ The second scene focuses on the arrival of Cartier, who brings with him both a Christian God and European civilization. As Davidson's narrative continues, a series of violent encounters occurs for the settlers or "nation-builders." These conflicts begin with "Indian raids" and are followed by the Jesuits' "death by torture" at the hands of Indigenous peoples, the dangers of a hostile and lonely wilderness, the Battle of Queenston Heights, and eventually the threat of the Great War.

\section{Progressive Elements and the Pageants' Themes}

The nature of the learning that was to take place in these historical pageants can be understood as a form of progressive education. While both pageants have scripts and instructions, they also allowed for and encouraged a great deal of experimentation, creativity, and collaboration. Medd's instructions to teachers in particular endorsed flexible classroom enactments for students with different ages and genders. Both pageants are explicitly designed to get students involved in their roles. As shown with the Muir example discussed in the pages of The School, pageants paid great attention to costumes, setting, and historical research, all of which were to be carried out by students and teachers in collaboration. The notion that students and teachers would spend classroom time to create a real-life pageant to be performed for a public audience that also embodied and taught the nation's history represented the essence of progressive education and its desire for real world activities and a greater attention to "extracurriculars." As von Heyking has noted, a key aim of progressive educators, along with social meliorism, was the desire to make school and learning more fun and engaging for students. Acting out a pageant of Canada's past in costume and in character surely met that goal. Of course, the historical narrative needed to interest students, which is why it is essential to think about how pageant authors like Medd and Davidson constructed a story that they believed would both engage young people in their nation's past and achieve the patriotic desires of politicians.

The social melioristic values of progressive pedagogy are also embedded in the narratives of these two pageants. While their content and themes differ, both pageants explicitly tell a story of different peoples or races coming together to improve the well-being of the greater community through co-operation and hard work in the face of adversity. While the pageants do create a narrow definition of what it means to be Canadian, they also suggest that social progress and economic prosperity involves "old settlers," newcomers, and Indigenous peoples coming together in a melting pot for everyone's benefit.

Both Medd and Davidson's pageants share the goal of celebrating the nation and its progress, however, the driving themes and historical focus of each pageant diverges significantly. Medd's pageant is primarily about Canada's abundant natural resources and its future promises of skillful, faithful, and committed labourers. In other words, 
The Crowning of Canada revolves around a dominant theme of economic progress as promoted by the federal government's suggestions. It is abundantly clear that each province, region, or group's value is associated with its economic production or labour in a capitalist economy. Though the pageant has historical elements and figures, it is ultimately future-facing in that it suggests that through its resources and the faith, love, and commitment of its citizens, Canada will become a great nation and will continue to thrive. This is embodied in the line: "The youngest nation of the earth and yet the greatest one." ${ }^{99}$ Davidson's pageant, on the other hand, makes scant mention of resources or crops essential to the young nation's future. In some respects, Medd's pageant embodies a new Canadian nationalism that emphasizes Canada's future potential rather than celebrating its imperial past as seen in Davidson's narrative.

The prevalence or lack of conflict is another important difference between Davidson's pageant and Medd's more sanitized tale. As with other pageants, such as the 1908 performance for the Quebec tercentenary, ${ }^{100}$ The Crowning of Canada pays little attention to conflict, violence, or suffering in Canada's past with the exception of minor mention of wars, such as the War of 1812 or the First World War, with unnamed foreign enemies. The only conflicts represented more completely in Medd's pageant were settlers' struggles with ambiguous concepts such as the wilderness or hardship. For example, Jacques Cartier's character states: "To colonize this land, my settlers left a land of ease, to suffer hardship, cold and disease." ${ }^{101}$ Likewise, the United Empire Loyalists face "toil and stress . . . in the forest wilderness." 102 No conflict between the French and the English is mentioned, nor is any question of conflict between settlers and Indigenous peoples raised.

In contrast, Davidson's pageant revolves around tales of settler bravery and honour, but also includes tales of violence, conflict, and struggle, often in opposition to a "savage" Indigenous population. The key theme of Canada: In Story and Song is the adventurous and romantic nature of Canada's past. This theme more directly resembles the narratives of pageants produced by imperialists like the IODE and at the 1908 Quebec tercentenary pageant. While progress is still embedded in the narrative, it is not a story of economic or resource development as it is in The Crowning of Canada. In fact, Davidson's decision to focus on romance and adventure might be understood as a decision made specifically with an eye to engaging students in the school subject of history, a subject that numerous progressive educators at the time referred to as full of "doldrums" and "drudgery." ${ }^{103}$ Violence and struggle remain dominant themes throughout the pageant, including its final lines read out by "Mother Canada:"

Now we are all one together, joined by the strongest bonds of a glorious past, we who have fought together and toiled together, we whose ancestors have lived lives of hardship to build a nation and whose friends have died deaths of horror to keep that nation's honour unstained. ${ }^{104}$

Such dramatization of the past into a story of heroes and villains demonstrates the power of pageants to be used simultaneously to inculcate students into a mythologized national identity while also asking them to learn by doing and playing. 


\section{Infantilizing, Erasing, and Replacing Indigenous Peoples}

In Medd's pageant, Indigenous peoples are noticeably absent throughout the majority of scenes, including areas that specifically talked about early colonization such as Cartier's landing. The only two places in the pageant where Indigenous people are represented is with the story of Tecumseh, who reminds the audience that Canada should not forget "the Braves who died for you," 105 and in the final scene, which is particularly revealing of Medd's perspective on Indigenous-settler relations. In this scene, a closing speech is made by the "Indian Chief" that placed Indigenous peoples in a position of submissive and naive childhood in relation to the Canadian state. This relationship is also interpreted as one of imagined Indigenous gratitude for the supposed benevolence of the state. The "Indian Chief" declares to Canada that "thou has taught us how to love, and thou has taught us how to pray, to work, to live fine, peaceful lives and we are proud to own thy sway." 106 In this speech, Indigenous people are portrayed as feeling indebted to Canada for its role in "civilizing" them, and in doing so, it makes invisible centuries of complex Indigenous-settler relations, including Indigenous resistance, co-operation, negotiation, and ongoing conflict with the settler colonial state.

In Davidson's pageant, Indigenous people are more present, but their representations remain static and dependent on European actors. Davidson's script provides a more detailed history of early colonization than Medd's does, and it describes the establishment of New France in more depth: "In spite of suffering and disease, savages and angry seas, settlers came out and forts were made, strong to resist an Indian raid." However, including more detail does not make the narrative more even-handed or historically accurate. ${ }^{107}$ The opening scene involves "a squaw and a brave" sitting around a campfire eating soup, banging on a drum, and smoking a peace pipe. After "the brave" tells a story of "how corn came to the Indians" (also provided by History Readers, Book II), an unnamed thief appears and steals the family's "papoose" (child) along with furs and a headdress, leaving "the squaw whimpering." The "brave" then sits and picks up his bowl of soup that "he drinks in silence, as Indians are not talkative." The "brave" then slowly describes how the Cree are thieves who steal goods and children, which will require a new alliance for war. ${ }^{108}$ This representation of Indigenous people reveals how Canadian pageants at the time constructed a dangerous and uncivilized "Indian Other" against which to project their own settler story of peace, order, and good governance. In the process, this also essentialized Indigenous conflict, erasing the role of contact, disease, and competition with European traders from the explanation of conflict between Indigenous peoples. In subsequent scenes of Canada: In Story and Song, Indigenous people fade into the background and only provide the occasional external threat to the events that unfold.

Another important difference in the representation of Indigenous peoples found in the two pageants is their place in Canada's present and future. In Davidson's pageant, Indigenous peoples are largely consigned to Canada's remote colonial past, as a dangerous obstacle to be overcome on the road towards the triumph of settler society. In Medd's pageant, not only are Indigenous people shown in the present, through 
the Chief s submissive and grateful speech, as making a contribution to Canadian nation-building, they are even assigned the highly symbolic role of crowning Miss Canada. This suggests the idea, vigorously promoted by the federal government, that Indigenous communities should be included in the jubilee celebrations as fully assimilated, modern Canadians, albeit only on terms set by settler society. ${ }^{109}$ Throughout both pageants, Indigenous people are represented in troubling and limited ways, such as childlike, dangerous, or "savage," or as grateful, assimilated Canadians. These representations of Indigenous peoples demonstrate the ways in which the colonial story of settler permanence was being constructed in Canadian schools in the 1920s.

\section{Gendered Roles and Expectations}

The two pageant scripts also teach gender roles alongside conceptions of national identity and Indigenous-settler relations. In Medd's pageant, women are represented in extremely limited ways, and only two characters explicitly portray women: Evangeline and Laura Secord. ${ }^{110}$ Poet Henry Wadsworth Longfellow's Evangeline represents the British expulsion of Acadians, which she refers to as a "mistake," because it separated her from her lover. Laura Secord's portrayal emphasizes "what women can do to make our nation great." After the pageant briefly recounts the tale of Secord warning British soldiers of the impending American attack, the student representing Secord declares: "Women can serve their land I'm sure, by being honest, kind and pure." The notion of a feminine purity and service to the state run throughout the pageant as each province is represented by young girls adorned with white cheese cloth, who are all described as serving the state in some way. ${ }^{111}$ The pageant's representation of women, as with the representation of Indigenous peoples, reinforces the supposed benevolence of the state, and simultaneously, certain groups' subservience to and reliance on it. In doing so, this pageant unsurprisingly helps uphold the settler colonial and patriarchal structures dominant at the time.

Davidson's pageant includes more women, although they are only given supporting, background, or allegorical roles, and only one female historical figure is mentioned by name: Marguerite de Roberval, the French noblewoman who became marooned on an island in the Gulf of St. Lawrence as she made her way to New France in the sixteenth century. The inclusion of de Roberval is an odd one considering the female characters commonly included in pageants at the time, such as Laura Secord. However, de Roberval functions in the pageant as both a morality tale and as a story of settler suffering and grief. The pageant explains: "Marguerite de Roberval, by cruel uncle's guile, because she loved beneath her rank, was marooned on a desert isle." The pageant then recounts how Marguerite's husband and child both died, but despite a broken heart, she survived and was rescued by sailors to tell her tale. ${ }^{112}$

The historical roles and expectations for men, and the boys who played them, are more numerous, but also limited in their nuances and complexity. The characters are primarily written to demonstrate qualities of strength, confidence, and power. Medd's John Cabot is described as brave and adventurous, while Champlain is gallant and brave. The European male characters all embody either a sense of power or 
daring, and they are often praised for their military conduct and honour. In contrast, Indigenous men and boys, in particular in Davidson's pageant, are portrayed as unnecessarily violent, wielding axes and bows and arrows without the honour granted to white characters. While these depictions of gender roles in pageantry are not particularly surprising, their performance in schools by children for other children is a stark reminder of the role education played in reinforcing patriarchal structures and teaching boys and girls about certain notions of masculinity and femininity.

\section{Performing the Past, Imagining the Future}

The interwar years in Ontario witnessed a range of educational shifts and tensions. Global political movements, modernization, and immigration dramatically changed the make-up of classrooms and the curriculum. History as a school subject rose in prominence as patriotic politicians and educators grappled with what it meant to be Canadian in an era of increasing globalism and growing American political and cultural hegemony. In this context, English Canadians looked to the past to find a narrative that could be used to create a through-line of identity that stretched from the modern settler colonial state back into the lives of imagined Indigenous "early Canadians." In reaching backwards to identify historical continuity, pageant writers, teachers, students, and audiences also looked to the future to project where this believed path of progress might take Canadians next, and how educators might contribute to the nation-building project. In these pageants, the symbolism of youth in the national imagination remained omnipresent for its importance in building a cohesive and strong settler state. At the same time, the government's preferred pageant narrative focusing on post-Confederation settlement, progress, and prosperity, while not fully replacing the older tale of imperial adventure and romance, established itself as a new national mythology that has remained in schools for generations.

The nationalist sentiments of the Diamond Jubilee coincided with the rise of progressive education, which entered its first "heyday" in North America and reached its peak in the mid-1930s. Progressive educators argued that students learnt best when they were learning by doing and playing. Asking students to embody and transform "historical" moments into real life lessons about belonging, national identity, Indigenous-settler relations, and gender expectations clearly met this vision. ${ }^{113} \mathrm{I}$ argue that the historical pageantry of the 1927 Diamond Jubilee of Confederation sits at the centre of these political and educational trends. In this moment, nationbuilding forces and progressive pedagogies aligned to promote the active and childcentred learning of a newly established historical narrative. Whether by choice or not, children across the country were swept into the pageant craze that had been growing in North American culture since 1905. As schools, teachers, and community groups staged mass spectacles of historical interpretation, an imagined community was being constructed and entrenched. Though the popularity of pageants did not last, falling out of favour during the Second World War, their legacy in the collective memoryscape has remained. 


\section{Notes}

1 The description of this pageant uses newspaper reports published in the Toronto Daily Star, the Globe, the Evening Telegram, and the Mail and Empire, which all reported on the pageant on May 27 and 28, 1927. The Globe began reporting on the pageant weeks earlier when it reported on a Catholic school board meeting in which trustees passed a motion to request the City of Toronto's permission to take a formal role in the Jubilee celebrations. At the meeting, School Trustee Battle was quoted as justifying their inclusion, stating "since we Catholics through our forefathers played so tremendous a part in the conquest and colonization of early Canada, we certainly should take a very prominent part." The board approved funding for the production of a historical pageant and planning began in earnest under the leadership of Rev. Brother Jarlath. "Separate School Children Preparing for Jubilee," Globe, May 14, 1927, 19.

2 "Beautiful Pageants Present Incidents in Canada's History," Globe, May 27, 1927, 11.

3 "Beautiful Pageants," Globe, May 27, 1927.

4 See the full script of the pageant The Story of Canada, published in the St. Lillies Annual Yearbook 16, no. 1 (June 1927), https://archive.org/details/stmstjosephlilies16testuoft/ page/n7.

5 "History of Dominion Covered in Pageant," Toronto Daily Star, May 2, 1927, 27.

6 "Beautiful Pageants," Globe, May 27, 1927, 11.

7 "Historical Incidents in Canada's History," Mail and Empire, May 27, 1927.

8 For discussions on how immigrant groups and Indigenous peoples used pageants as vehicles for affirming their own identities, despite the official vision generated by the government, see Robert Cupido, "Appropriating the Past: Pageants, Politics and the Diamond Jubilee of Confederation," Journal of the Canadian Historical Association 9, no. 1 (1998): 155-86; and Robert Cupido, "Public Commemoration and Ethnocultural Assertion: Winnipeg Celebrates the Diamond Jubilee of Confederation," Urban History Review 38, no. 2 (2010): 64-74.

9 See Canada, Executive Committee of the National Committee for the Celebration of the Diamond Jubilee of Confederation, "Minutes of Proceedings of the Executive Committee for the Celebration of the Diamond Jubilee of Confederation," Confederation Diamond Jubilee Collection, 1927-28, boxes MU 750 and MU 751, fonds F1067, Archives of Ontario, Toronto.

10 The phrase "fire the imagination of our future citizens" comes from the introduction to A. M. Stephen, Classroom Plays from Canadian History (Toronto: J. M. Dent \& Sons, 1929).

11 See Cupido, "Appropriating the Past." For a discussion on pageants produced by the Imperial Order Daughters of the Empire (IODE), see Allana Lindgren, "Amy Sternberg's Historical Pageant: The Performance of IODE Ideology during Canada's Diamond Jubilee," TRiC/RTaC 32, no. 1 (2001).

12 For a discussion of progressive education in Ontario during the interwar years, see Theodore Christou, Progressive Rhetoric and Curriculum: Contested Visions of Public Education in Interwar Ontario (New York: Routledge, 2018).

13 See Tom Hulme, "A Nation of Town Criers: Civic Publicity and Historical Pageantry in Interwar Britain," Urban History 44, no. 1 (2017); and David Glassberg, American Historical Pageantry: The Uses of Tradition in the Early Twentieth Century (Chapel Hill, NC: University of North Carolina Press, 1990). Historians of the "new pageantry" credit British dramatist and musician Louis Napoleon Parker with helping to create this movement. Parker staged his first pageant in Sherbourne, England, in 1905.

14 Glassberg, American Historical Pageantry, remains the key work on historical pageants in the United States.

15 For a discussion on how settler colonialism operates to secure "settler futurity" in relation to education, see Eve Tuck and Rubén Gaztambide-Fernández, "Curriculum, 
Replacement, and Settler Futurity," Journal of Curriculum Theorizing 29, no. 1 (2013): 72-89.

16 For a discussion of anti-modernism's relationship to historical pageantry, see Glassberg, American Historical Pageantry, 35.

17 See Hulme, "A Nation of Town Criers," and Glassberg, American Historical Pageantry.

18 H. V. Nelles, The Art of Nation-Building: Pageantry and Spectacle at Quebec's Tercentenary (Toronto: University of Toronto Press, 1999).

19 See Heather Fitzsimmons-Frey, "Singing and Dancing 'Their Bit' for the Nation: Canadian Children's Performances for Charity circa the First World War," Jeunesse. Young People, Texts, Cultures 9, no. 2 (2017): 43-68, for a discussion of how children's pageants were used to raise funds during the First World War.

20 See Cupido, "Appropriating the Past," for a more in-depth explanation of why 1927 was seen as an important opportunity for nation-building and commemoration, which, in part, was because the fiftieth celebrations had been fairly muted due to the First World War.

21 Canada, Bill 65, An Act to Incorporate a National Committee for the Celebration of the Diamond Jubilee of Confederation, First Session, Sixteenth Parliament, 17-18 George V, 1926-1927. F. C. Acland, Printer to the King's Most Excellent Majesty, 1927.

22 Canada, House of Commons Debates, 16th Parliament, February 15, 1927, 351.

23 Their request came alongside the desire for additional representatives from labour and agricultural organizations.

24 Canada, House of Commons Debates, 16th Parliament, February 17, 1927, 350, 411-15.

25 Canada, House of Commons Debates, 16th Parliament, 351.

26 Canada, Bill 65, February 17, 1927.

27 Canada, Executive Committee of the National Committee for the Celebration of the Diamond Jubilee of Confederation, Final Report of the Executive Committee, 7.

28 R. H. Coats, ed., Sixty Years of Canadian Progress, 1867-1927 (Ottawa: National Committee for the Diamond Jubilee of Confederation, 1927).

29 A new Canadian coat of arms was introduced in 1921, replacing the British coat of arms.

30 See Robert M. Stamp, The Schools of Ontario, 1876-1976 (Toronto: University of Toronto Press, 1982).

31 Canada, Diamond Jubilee of Confederation: General Suggestions for the Guidance of Committees in Charge of Local Celebrations (Ottawa: Executive Committee of the National Committee for the Diamond Jubilee of Confederation, 1927); and Canada, Diamond Jubilee of Confederation: Suggestions for Historical Pageants, Floats and Tableaux for the Guidance of Local Committees in Charge of Diamond Jubilee Celebrations (Ottawa: Executive Committee of the National Committee for the Celebration of the Diamond Jubilee of Confederation, 1927).

32 Canada, Suggestions for Historical Pageants, Floats and Tableaux.

33 New Brunswick Department of Education, Report of the Superintendent of Education of the Province of New Brunswick (Fredericton: King's Printers, 1927), liii.

34 Quebec Ministry of Education, Report of the Superintendent of Education of the Province of Quebec (Quebec: King's Printers, 1927), 478.

35 Canada, Final Report of the Executive Committee.

36 All numbers were reported in the National Committee's final report. The nature of celebrations was reported to the committee by each provincial secretary at a national conference held on September 8, 1927. Newspapers reported similar numbers, including the Globe on July 3, 1927.

37 Trenholme was eventually a founder of the Hamilton branch of the Imperial Order Daughters of the Empire (IODE), which played an important role in producing pageants for the Diamond Jubilee celebrations in 1927. 
38 See Stamp, Schools of Ontario, and Michihisa Hosokawa, "Making Imperial Citizens: Empire Day in Canada," Journal of American and Canadian Studies 25 (2007): 49-73.

39 Stamp, Schools of Ontario, 105.

40 Stamp, Schools of Ontario, 105.

41 Stamp, Schools of Ontario.

42 Ontario Department of Education, Empire Day in the Schools of Ontario (Toronto: King's Printers, 1925), 3.

43 Ontario, Empire Day, 7.

44 Canada, Report of the Executive Committee, 35.

45 See Stamp, The Schools of Ontario, 173-76, for a discussion of how the purposes of the Empire Day movement slowly shifted in the 1920s and 1930s away from imperialism and militarism towards strengthening a new Canadian identity. See also Ken Osborne, "Canadian Schools, The League of Nations, and the Teaching of History, 1920-1939," Historical Studies in Education/Revue d'histoire de l'éducation 30, no. 2 (2018): 1-23.

46 Robert M. Stamp, "Empire Day in the Schools of Ontario: The Training of Young Imperialists," Journal of Canadian Studies 8, no. 3 (1973): 41.

47 Marcel Martel, Allison Marie Ward, Joel Belliveau, and Brittney Ann Bos, "Promoting a 'Sound Patriotic Feeling' in Canada through Empire Day, 1899-1957," in Celebrating Canada, ed. Raymond B. Blake and Matthew Hayday (Toronto: University of Toronto Press, 2016), 119.

48 Canada, Report of the Executive Committee, 34.

49 Canada, Report of the Executive Committee, 35.

50 "Model School Pupils Presented a Pageant," Toronto Daily Star, June 29, 1927.

51 "Birthday Cake for the Jubilee," Globe, June 28, 1927.

52 City of Toronto, "Military and Historical Pageant Program," July 1, 1927, City of Toronto Archives.

53 See "Totem Poles, Tepees, and Token Traditions: 'Playing Indian' at Camp," in Sharon Wall, The Nurture of Nature: Childhood, Antimodernism, and Ontario Summer Camps, 1920-1955 (Vancouver: UBC Press, 2009).

54 For a more thorough discussion of Indigenous participation in commemorative rituals, including some explication for their motivations, see Henry Nelles, The Art of NationBuilding: Pageantry and Spectacle at Quebec's Tercentenary (Toronto: University of Toronto Press, 2000); and Cupido, "Appropriating the Past."

55 See "Pageant Depicts Makers of Canada," Mail and Empire, July 2, 1927. Weeks before the parade, Roy Mitchell had sent out a call to the schools for a hundred children of high school age who could sing.

56 "Pageant Depicts Makers of Canada," Mail and Empire, July 2, 1927.

57 Jean Belliveau and Marcel Martel, "One Flag, One Throne, One Empire? Espousing and Replacing Empire Day in French Canada, 1899-1952," in Celebrating Canada, ed. Raymond B. Blake and Matthew Hayday (Toronto: University of Toronto Press, 2016), 128.

58 "New History" was the term commonly applied in progressive educational circles to refer to new methods of teaching and learning history that often emphasized projects and using primary sources, as opposed to traditional methods that used lectures and rote learning of historical facts.

59 See Lorne Pierce, New History for the Old: Discussions on Aims and Methods in Writing and Teaching History (Toronto: Ryerson Press, 1931), 67.

60 Pierce, New History for the Old, 67.

61 Theodore Christou, Progressive Education: Revisioning and Reframing Ontario's Public Schools, 1919-1942 (Toronto: University of Toronto Press, 2012), 44.

62 "Editorial Notes," The School 15, no. 9 (May 1927): 847. 
63 See Christou, Progressive Education, for a discussion of how The School and the Canadian School Board Journal were the two dominant Canadian publications where progressive education advocates could share their ideas.

64 Minnie Harvey Williams, The Romance of Canada: An Historical Pageant (Toronto: Ryerson Press, 1923).

65 Shirley Muir, "A School Pageant," The School 15, no. 1. (September 1926): 17.

66 Muir, "School Pageant": 18.

67 Muir, "School Pageant": 18.

68 See Cupido, "Appropriating the Past."

69 See Amy von Heyking, "Implementing Progressive Education in Alberta's Rural Schools," Historical Studies in Education/Revue d'histoire de l'éducation 24, no. 1 (2012): 93-111.

70 Cynthia Comacchio, The Dominion of Youth: Adolescence and the Making of Modern Canada, 1920 to 1950 (Waterloo: Wilfrid Laurier University Press, 2006), 99.

71 See Christou, Progressive Rhetoric and Curriculum, and Christou, Progressive Education.

72 See Katherine Mayhew and Anna Edwards, The Dewey School: The Laboratory School at the University of Chicago 1896-1903 (London: Atheron Press, 1965). Mayhew and Edwards were both teachers at the Dewey laboratory school who experimented with different "progressive" methods for teaching history.

73 See Glassberg, American Historical Pageantry, 55-58, for his discussion of Dewey and McMurray regarding pageantry.

74 Charles A. McMurray, Special Methods in History: A Complete Outline in History for Grades Below the High School (New York: Macmillan, 1903), 13.

75 See W. Whittles, "Dramatisation in History," The Practical Teacher 32 (1911): 7-8, and Horace Brown, "Dramatization in History Teaching," The Elementary School Teacher 13 (1913): 425-33.

76 Brown, "Dramatization in History Teaching," 425.

77 Brown, "Dramatization in History Teaching," 427.

78 See von Heyking, "Implementing Progressive Education in Alberta's Rural Schools," and Christou, Progressive Rhetoric and Curriculum. For a more specific look at history teaching, see Ken Osborne, "Teaching History in Schools, A Canadian Debate,"Journal of Curriculum Studies 35, no. 5 (2003): 585-626.

79 See Ken Osborne, "Its Prospects Are by no Means Hopeless: A 1923 Report on the State of History Teaching in Canadian Schools," Canadian Social Studies 35, no. 4 (2001), for a discussion of the 1923 report on history and civics education in Canada. In the 1920s, historians still held a major stake and interest in school history. The report was critical of the state of history education and advocated for history to be more relevant and meaningful in Canadian classrooms, though this was decidedly not a call for progressive education.

80 Ruth and Evangeline Lewis, "Dramatization of History," The School 15, no. 10 (June 1927).

81 "Talks on Education," Globe, June 11, 1927, 25.

82 Ruth and Evangeline Lewis, "Dramatization of History," 959.

83 Ontario Department of Education, Methods for Elementary Schools: History (Toronto: King's Printers, 1917).

84 Nellie Medd, The Crowning of Canada: A Jubilee Confederation Pageant (Toronto: King's Printers, 1927); True Davidson, Canada: In Story and Song (Toronto: J. M. Dent and Sons, 1927).

85 Nellie Medd was a teacher in Exeter, Ontario. True Davidson taught in Manitoba, Saskatchewan, and Ontario. 
86 Other historical pageants written for schoolchildren prior to this period include the work of Edith Groves, who wrote a series of patriotic pageants between 1916 and 1919 with names such as "Miss Canada" and "The Wooing of Miss Canada."

87 Canada, Report of the Executive Committee, 36.

88 See Report of the Executive Committee, 36. The report states that the pageant was produced with great success by a number of schools, though no specifics exist on how many schools participated. Since the pamphlet was distributed to every school in the province, it is fair to assume that many children performed this pageant.

89 Medd, The Crowning of Canada, 7.

90 See Medd, The Crowning of Canada, 7, which provides suggestions for each character's costume using materials that could be easily found by students in their homes.

91 Medd, The Crowning of Canada, 3.

92 Medd, The Crowning of Canada, 3-6.

93 Diademeta is an Anglican hymn written in 1868 by George Elvey and originally entitled "Crown Him with Many Crowns."

94 See Eleanor Drake, Call Me True: A Biography of True Davidson (Toronto: Natural Heritage, 1997).

95 Donalda J. Dickie, Dent's Canadian History Readers: All About Indians (Toronto: J. M. Dent and Sons, 1926). Most of Dent's Canadian History Readers are archived and available online at https://archive.org/details/dentscanadianhis02dick.

96 Dickie, Dent's Canadian History Readers.

97 Davidson, Canada: In Story and Song, 3.

98 Davidson, Canada: In Story and Song, 6.

99 Medd, The Crowning of Canada, 7.

100 See Nelles, The Art of Nation Building.

101 Medd, The Crowning of Canada, 5.

102 Medd, The Crowning of Canada, 4.

103 See Ruth and Evangeline Lewis, "Dramatization of History": 959-60.

104 Lewis, "Dramatization," 14.

105 Medd, The Crowning of Canada, 4.

106 Medd, The Crowning of Canada, 6.

107 Lewis, "Dramatization," 9.

108 All quotations used in this scene are found in Davidson, Canada: In Story and Song, 6-7.

109 See Canada, General Suggestions for the Guidance of Committees in Charge of Local Celebrations, 6. The suggestion states: "If there are Indians in the vicinity they should be asked to participate."

110 See Colin M. Coates and Cecilia L. Morgan, Heroines and History: Representations of Madeleine de Verchères and Laura Secord (Toronto: University of Toronto Press, 2002), for an in-depth study of the representation of women in Canada's past, including Laura Secord.

111 See Robyn Fowler, "Miss Canada and the Allegory of Nation" (PhD diss., University of Alberta, 2005) for a discussion of women representing Canada. Jane Nicholas, "Gendering the Jubilee: Gender and Modernity in the Diamond Jubilee of Confederation Celebrations, 1927," Canadian Historical Review 90, no. 2 (2009): 247-274.

112 This version of the story likely comes from the Queen of Navarre's retelling of the event in the "Heptameron," a collection of short stories that focused on romance, love, and adventure in the seventeenth century.

113 See Mona Gleason, "Metaphor, Materiality, and Method: The Central Role of Embodiment in the History of Education," Paedagogica Historica 54, no. 1-2 (2018): 4-19, for a fuller discussion on the importance of thinking about embodiment in educational histories. 